\title{
Lagging behind or catching up? The mechanization of the Portuguese cork industry (1880-1914)
}

\author{
- Carlos Manuel Faísca \\ Universidad de Extremadura | Município Ponte de Sor
}

\section{Introduction}

Nowadays the Portuguese cork industry leads the world market, with more than two thirds of the world industrial exports of cork coming from Portugal, ${ }^{1}$ an amount that is expected to have exceeded 1 billion euros in 2018 . The largest company in the sector is the Portuguese Corticeira Amorim, based in Santa Maria da Feira, with 30 industrial units spread across six countries, ${ }^{2}$ a sales volume of more than 700 million euros, a stock market capitalization of circa 1.4 billion euros ${ }^{3}$ and employing around 4,200 workers. ${ }^{4}$

However, in the nineteenth century, the core of the cork industry was located in Spain, especially in Catalonia, with the rise of Portugal as the world leader of the cork sector an issue explored by Santiago Zapata Blanco and, mainly, by Francisco Parejo Moruno. ${ }^{5}$ Although they studied several characteristics of the cork industry in the nineteenth century, their focus was essentially the 1930s and 1940s, when the positions of Spain and Portugal reversed. These two authors, supported also by other works on the twentieth-century Iberian cork industry, ${ }^{6}$ concluded that a broad range of structural factors were at the root of this change in the cork business, in addition to conjunctural factors like the Great Depression (1929) and the Spanish Civil War (1936-1939). In addition to the Portuguese ecological advantage regarding the

1. Associação Portuguesa de Cortiça (2018), p. 18.

2. Corticeira Amorim, S.G.P.S., S.A. (2018), pp. 12-13.

3. Corticeira Amorim, S.G.P.S., S.A. (2018), p. 41.

4. Corticeira Amorim, S.G.P.S., S.A. (2018), p. 39.

5. Zapata Blanco (2002); Parejo Moruno (2009).

6. Namely Branco (2005), García Pereda (2008) and García Pereda (2009).

Fecha de recepción: noviembre 2018

Versión definitiva: enero 2019

Revista de Historia Industrial

N. ${ }^{\circ}$ 76. Año XXVIII. 2019 
supply of raw material, the structural factors were Portuguese forestry and scientific state policy, as well as the action of the Junta Nacional de Cortiça on matters such as education, coordination of the industrial sector and the promotion of Portuguese products in international markets. The conclusions were based on the comparison between the Portuguese and Spanish cork sectors, since also in this period the more industrialized countries lost significance in the industrial transformation of cork. These, like the United Kingdom, the United States of America and Germany, gained importance in the mid-nineteenth century due to the early mechanization of cork stopper production, a vital process, which in Spain only began in the 1880s, regaining part of the region's lost preponderance. This important technological change in the cork industry has already been studied for Spain, ${ }^{7}$ but remains to be explored in the case of the Portuguese cork industry.

In this article, we revert the analysis to the second half of the nineteenth century, in order to understand the technological modernization of the Portuguese cork industry, knowing that the Spanish cork industry was mechanising so as not to lose competitiveness. From this question arise two fundamentals goals. The first one is to understand its eventual delay regarding the Spanish chronology thus explaining, at least in part, the backwardness of the Portuguese cork industry compared with the Spanish one in the late nineteenth century. On the other hand, if a process of mechanization chronologically similar to the Spanish is detected, it helps to explain the rise of the cork industry in Portugal as a world leader three decades later. For this reason, the chronological period of this work begins in the 1880s, precisely when the first signs of the use of machinery appeared in the Spanish cork industry, and ends with the beginning of the First World War. This conflict caused a crisis in the cork sector due to the decrease of international trade, as well as the fact that the largest importers of Iberian cork (France, United Kingdom, United States of America, Russia and Germany) were the main belligerents. ${ }^{8}$ After the conflict, the dissemination of the production of cork agglomerate changed the cork business completely. Among other factors, there was a strong economic valorisation of the inferior quality cork and the need for large investments in fixed capital emerged, so the comparative study of the introduction of this new technology into the Iberian cork industry is to be explored in another future work. The second goal is to contextualize the "modernization" of the cork industry within the general Portuguese industry, knowing that the cork industry was one of the most important industrial sectors of the Portuguese economy.

The geographical delimitation of this study to the Iberian Peninsula is explained mainly by the fact that these two countries led the cork industry over

7. Zapata Blanco (1996); Espadalé (2002); Alvarado i Costa (2004).

8. Parejo Moruno (2009), pp. 140-149. 
the last two hundred years. In fact, despite the significant existence of cork industries in other countries, from the mid-eighteenth century either Spain or Portugal dominated the sector. ${ }^{9}$

In order to fulfil the established goals, after briefly explaining the industrial process of cork stopper production in the nineteenth century and the geographical distribution of the cork industry worldwide, we describe and review the sources and methods. Then we analyse, from a comparative perspective, the mechanization of the Portuguese and Spanish cork industries from the two principal industrial cork regions of the nineteenth century in those countries: Catalonia, and the south of Portugal, looking with some detail at the local differences in the Portuguese case. Finally, we concluded that there wasn't any special delay in the integration of machinery in the Portuguese cork industry compared to the Catalan process, existing, at most, a gap in the type of machinery used. In fact, the information gathered suggests that in the south of Portugal manually-operated machines predominated - essentially garlopas - while in Catalonia, after a first similar phase, several machines were introduced that were moved by inanimate energy, although this second phase of technological modernization was only definitively imposed after the end of the First World War. In addition, the limited information available regarding the cork industry present in the Lisbon region points to a mechanization scenario not only with garlopas, but also with machines moved by inanimate energy. Therefore, the Portuguese cork industry was closely following the modernization of the Spanish cork industry and it's more than plausible that, in this important aspect, they could compete with each other. As a matter of fact, both regions had some similarities with fully mechanized factories, while others, usually small units, maintained a manual production process. On the other hand, the Portuguese cork industry trailed the typical pattern of "modernization" in Portuguese industry: a late start, but followed by a relatively rapid process of substitution of labour for capital.

\section{The cork industry in the second half of the nineteenth century: industrial process and products}

In the nineteenth century, the cork industry essentially produced natural cork stoppers, since agglomerate cork emerged as the main product only after the First World War. ${ }^{10}$ In the production of cork stoppers there were two essential phases: the first was the preparation of cork, made by the "preparatory" industry, and, afterwards, the transformation of cork, made by the manufacturing industry.

9. Branco [et. al.] (2016).

10. Parejo Moruno (2009), pp. 127-129. 
The "preparatory" industry, with a low-value output, as its name implies, was responsible for the manufacture of intermediate products, namely cork board, which was then processed into stoppers by the manufacturing industry. In the "preparatory" industry, the factory usually consisted of a large open space where, after being extracted from the tree, the cork boards were piled without any treatment and/or in a building, sometimes described as "[...] a large barrack [...]", ${ }^{11}$ where the cork was cooked. There were also warehouses to store the cork boards that were already cooked, packed and, thus, ready to be shipped to the manufacturing factories. ${ }^{12}$

The manufacturing industry, which generated most of the value added of the cork business, produced cork stoppers manually with the use of a knife in a handicraft way, until the mid-nineteenth century. Therefore, there was a great valorisation of the worker and many small businesses thrived because with a small investment it was possible to build a "factory". However, in the mid-nineteenth century, beginning in the most industrialized countries, such as France, the United Kingdom, Germany and the United States of America, mechanized solutions for the production of corks appeared. In France the garlopa was developed, a machine, which, nevertheless, still depended on the physical effort of the worker; whereas the United States introduced the drilling machine, popularly known as "machine guns", ${ }^{13}$ which was moved by a pedal or by using small engines. There were also the emery machines, totally dependent on inanimate energy, that through rotary discs coated with an abrasive material, turned cork board into a stopper. ${ }^{14}$ Chronologically, the garlopa dates from the mid-nineteenth century, the drilling machine from the $1880 \mathrm{~s}$, and the emery machine from the late nineteenth century. ${ }^{15}$

As with other industrial sectors, the introduction of this machinery allowed an exponential increase of production in quantity but not in quality, so the higher quality corks, and especially those intended to seal sparkling wines like Champagne, maintained for some time a handicraft logic. However, productivity differences were so large that, despite the resistance from manual workers, the mechanization of the cork industry was successful. It's sufficient enough to understand it by comparing that while a good manual worker produced up to 1,500-2,000 cork stoppers per day, a garlopa could manufacture 6,000 cork stoppers per day and the drilling machine could, depending on the engine, make $20,000-40,000$ cork stoppers per day. ${ }^{16}$ Later, the

11. Júnior (1923), p. 325.

12. Júnior (1923), pp. 323-326.

13. Parejo Moruno (2010), pp. 34-35.

14. Sala (2000), p. 283.

15. Sala, Nadal (2013), p. 71.

16. Júnior (1923), p. 56-58. 
improvement of the machinery for the production of cork stoppers allowed the replacement of almost all the manual production. ${ }^{17}$

\section{Industrial geography of the cork industry in the second-half of nineteenth century}

Despite its presence in international European trade since Ancient Rome ${ }^{18}$ and during the Middle Ages, ${ }^{19}$ the systematic exploitation of cork began in France, in the late seventeenth century, due to the need to manufacture stoppers in order to provide the local wine production. ${ }^{20}$ Thus, the first nucleus of the cork "industry" developed in the French regions of cork forest production such as Roussillon. ${ }^{21}$ However, due to the geographical distribution of the cork oak tree, the demand for raw cork expanded towards Catalonia, already in the mid-eighteenth century, as French production quickly proved to be insufficient to meet the increased need for the production of cork stoppers. In addition, the cork industry also established in this region of northern Spain, rapidly making Catalonia the centre of the world's cork industry. Meanwhile, in some non-raw cork producing countries, such as Germany and the United Kingdom, the cork industry developed from the import of raw materials from Spain and, above all, Portugal. In the nineteenth century, there was a strong growth in wine consumption, despite several problems in its production related to pests and diseases, like powdery mildew and phylloxera, ${ }^{22}$ so that Catalan production was also not enough to supply the needs of the growing wine industry. Therefore, forest exploitation and the industrial transformation of cork became established in the world's largest cork oak area: the south-west of the Iberian Peninsula (southern Portugal and the Spanish provinces of Extremadura and Andalusia). ${ }^{23}$

Catalan domination of the cork industry started to be threatened with the technological development of the industry in the more advanced economies that, beginning in the 1850 s, introduced a great variety of machinery to the production of cork stoppers, making their output extremely productive com-

17. Parejo Moruno (2009), pp. 124-125.

18. Bombico, Carneiro (2016).

19. Soldevila i Temporal (2009).

20. Tradition attributes to the Benedictine monk Pierre Pérignon the "invention" of the cork stopper. They were used as seals on bottles of the sparkling wine that D. Pérignon produced in the French region of Champagne. However, some recent studies refuted this romantic story, for instance, see Santos (2009).

21. Voth (2009), p. 581.

22. Simpson (2011).

23. Parejo Moruno, Faísca, Rangel Preciado (2013); Fonseca (1996). 
pared to the "traditional" Iberian industry. ${ }^{24}$ Indeed, taking into account that the artisanal knowhow and the raw material resided in the Iberian Peninsula, greatly increasing the costs of processing cork outside Iberia, the only way for the cork industry to develop strongly in non-cork producing countries was through a "technological shock" that made it more competitive. In fact, the first records of mechanized stopper production in the United States date back to $1853,{ }^{25}$ with the early mechanization of cork production being one of the factors associated with the growth of John D. Glass \& Company, in the 1860s. This company, in turn, would lead to the creation of the Armstrong Cork Company, one of the world's leading companies in the first half of the twentieth century. ${ }^{26}$

However, this technological transformation that began in the mid-nineteenth century did not immediately affect the Iberian industry, not only because of the great increase in demand for cork stoppers, as a result of the spread of wine consumption throughout the world, but also because mechanization initially only allowed the production of low-quality corks, keeping much of the market intact. However, as the twentieth century approached, the situation changed with the improvement of mechanized production, seriously threatening the dominant position of the Iberian industry in general, and Catalonia in particular.

In Portugal, the cork business was essentially raw material exportation, since in the mid-nineteenth century only $5 \%$ of the cork was transformed within its borders. ${ }^{27}$ Throughout the nineteenth century, however, the Portuguese "preparatory" industry and the manufacturing industry developed and, on the eve of the Great War, almost half of Portuguese cork was exported as a processed product. ${ }^{28}$ Even so, compared with the Spanish industry, concentrated mainly in Catalonia, the Portuguese industry was much smaller, and lost a large share of the potential added value of the national cork business through a significant amount of exportation of raw material and/or just prepared cork instead of processed products. Suffice to say that, in 1900, while in Spain there were 1,250 factories employing more than 34,000 workers, in Portugal there were "only" 115 factories with a total manpower of approximately 5,000 workers. ${ }^{29}$

Thus, it is important to understand how the Portuguese cork industry responded to the process of the mechanization of the Spanish cork industry, to determine if this aspect was also a reason for the loss of competitiveness that

24. Parejo Moruno (2009), pp. 119-121

25. Espadalé (2002), p. 541.

26. Grupo de Estudios de Historia Rural (1999), pp. 1309-1310.

27. Parejo Moruno (2009), p. 85.

28. See the data published by Mendes (2002), p. 149-152.

29. Parejo Moruno (2009), p. 88. 
MAP 1 - World natural potential distribution of the cork oak tree

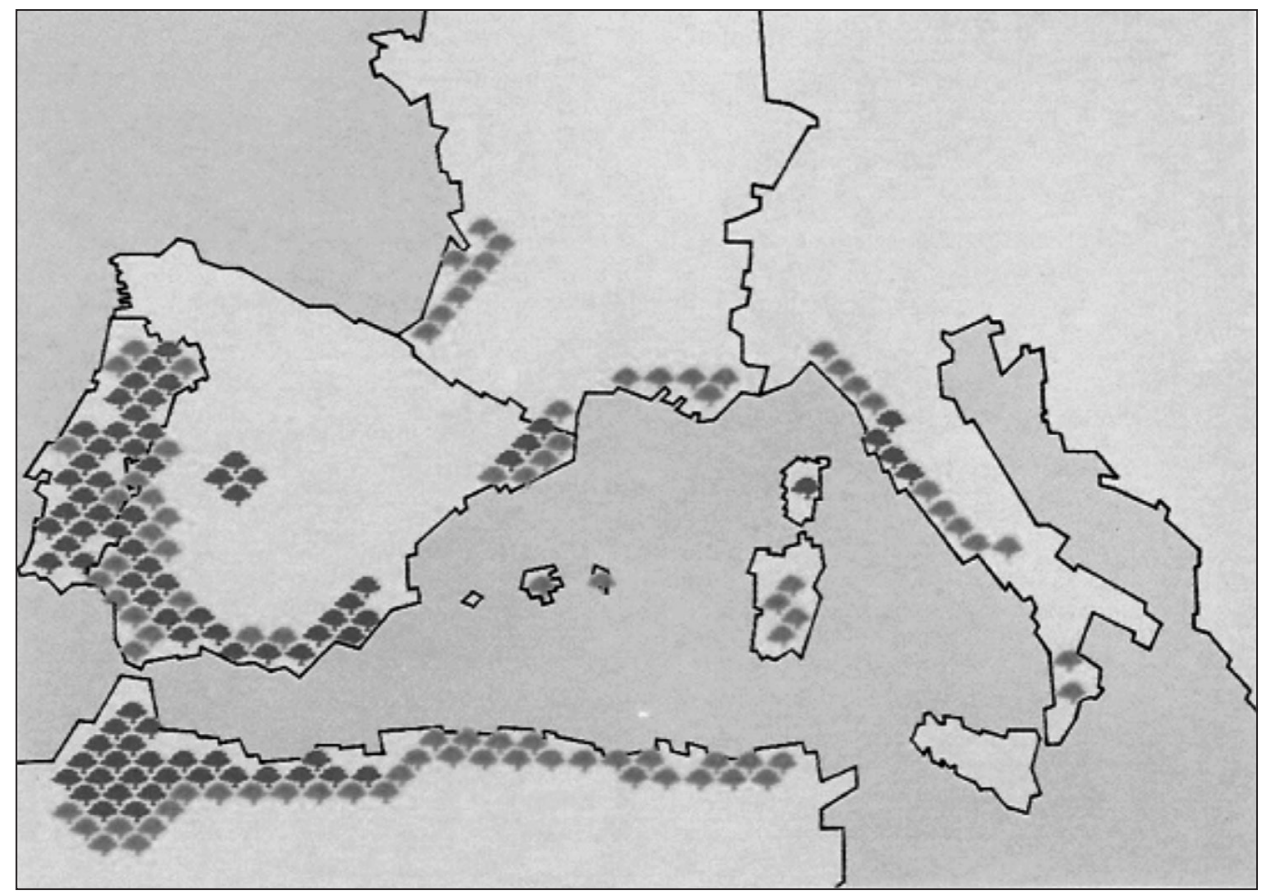

Source: Oliveira, Oliveira (1991).

would help explain the apparent underutilization of the Portuguese natural cork oak resources. Indeed, it is in Portugal that the cork oak tree finds its ecological optimum and has the largest area of forestation, so there is a natural advantage regarding the offer of raw material already reflected in the world production of raw cork by 1880 . In those days, Portugal had a $46 \%$ world share of raw cork production, followed by Spain (26\%), Algeria (13\%), France $(9 \%)$ and Italy $(7 \%) .{ }^{30}$

\section{Sources and methods}

In this work, for analysing the mechanization process of the Spanish cork industry, we use secondary sources, i.e., bibliography, because the subject was already studied in the Spanish economic historiography. However, that is not the case for the Portuguese cork industry. Therefore, in addition to bibliography, both from the nineteenth century and contemporary, several primary sources are used. Two Industrial Inquiries (1880 and 1891); two Industrial

30. Mendes (2002), p. 98. 
Statistics produced by the 4th Industrial District, a structure of the Central Administration of the Portuguese State under the Ministry of Public Works, Commerce and Industry (referring to 1895 and 1901-03); and, finally, the statistics produced by the Cork Industry Inspection Commission (between 1913 and 1917).

The Industrial Inquiries are one of the "classic" sources for knowledge of nineteenth-century Portuguese industry, since they are the first great effort of the Portuguese State to know the condition of national industries. The first Inquiry that we use, launched in $1881,{ }^{31}$ was divided between a direct inquiry, in which the employees of the Ministry of Public Works, Commerce and Industry checked the working factories on-site; and an indirect inquiry, where the owners themselves answered an optional questionnaire that was sent to them. Unfortunately, with the exception of the districts of Oporto, Guarda and Castelo Branco, other districts in the country either participated only in the indirect survey or did not participate in any way. Only $10 \%$ of the questionnaires were answered, there were huge inequalities in the responses gathered and in many cases no information was sent. ${ }^{32}$ In this context, the Industrial Inquiry of 1881 is more worthy for the information that it actually contains, rather than the missing information. That is to say, not pointing out a factory in a given location or the inexistence of machinery in an identified factory, does not confirm this reality, but, on the contrary, it will certainly be more plausible to consider what the survey indicates, like factories, machines, number of workers, and so on.

The Industrial Inquiry of $1890^{33}$ was much more extensive and exhaustive than its predecessor, since the ministerial collaborators travelled around the country, installing special commissions in the district headquarters and, in the municipalities, local commissions that worked with the local public administrator. However, the quality and quantity of the information does deserve some attention and it is suffice to mention that the large cork plant of Portalegre, perhaps the largest in Portugal, is not included in this document because its owner, George Robinson, refused any type of collaboration. ${ }^{34}$ As matter of fact, while in some places, such as Grândola and Odemira, the work seems to have taken place "[...] without omissions or inaccuracies $[\ldots]$ ", ${ }^{35}$ in others, like Évora or Estremoz, there was great distrust on the part of the owners for the "[...] belief that these questionnaires are preparatory for new contributions $[\ldots] " .{ }^{36}$ Thus, and notwithstanding the greater magnitude of this

31. Portugal. Ministério das Obras Públicas, Comércio e Indústria (1881-1883).

32. Silva, Garcia (1981).

33. Portugal. Ministério das Obras Públicas, Comércio e Indústria (1891).

34. Portugal. Ministério das Obras Públicas, Comércio e Indústria (1891), p.419.

35. Portugal. Ministério das Obras Públicas, Comércio e Indústria (1891), p. 35.

36. Portugal. Ministério das Obras Públicas, Comércio e Indústria (1891), p. 520. 
source, the interpretation that is made of it has the same logic as that of the previous Industrial Inquiry.

Then, we use two works done by a team led by the engineer Adriano Monteiro, Chief of the 4th Industrial Circumscription that corresponded, geographically, to the districts of Évora, Beja and Faro. The first one, entitled Cadastro das Indústrias da $4 .{ }^{a}$ circunscrição a 30 de junho de $1895,{ }^{37}$ was published in different numbers of the Boletim do Trabalho Industrial between that year and 1905. The second was published in 1905 by the National Press in a monograph entitled Estatística Industrial dos Distritos de Évora, Beja e Faro, but it reports on the period 1901-03..$^{38}$ The reliability of these sources deserves more credit than the previous, since there was an effort of direct observation on the part of its producers, with civil engineer Francisco de Salles Fernandes Gião, in the latter case, under the supervision of Adriano Monteiro, personally visiting the factories in the regions.

Finally, we analyse the documents produced by the Cork Industry Inspection Commission. This organization was created by the Decree of 22 November 1910, following the prohibition of the export of all cork that was not cooked, scraped, trimmed and properly bandaged. Several circumscriptions were then established and, in each one, a committee had the task of preparing a statistical report. This document indicated the number and value of the checked cork burdens; the names of the manufacturers; the destination of the cork dispatched by each manufacturer; the number and value of cork burdens left in Portugal for the manufacture of cork boards or stoppers; and, finally, the number and type of workers employed in each factory. In the south of Portugal the circumscriptions of Portalegre, Vendas Novas, Évora, Alcácer do Sal, and Sines, in the Alentejo, were created; and Faro and Silves in the Algarve. It is difficult to analyse the validity of this source, but after an extremely socially bellicose period, known as the "Questão corticeira", from which the above legislation came out, it's expected that there would be some caution in collecting information about the sector. In addition, Article 2 of the aforementioned decree imposed a supervisory commission consisting of a worker elected by the labour unions, an independent representative appointed by the government and the owner or his legal agent of the inspected factory. In this way, the different interests in the industrial cork business were properly represented.

The measurement of the "mechanization" of the Portuguese cork industry was restricted to the south of Portugal, namely the geographical areas of Alentejo and Algarve. The former corresponds to the sum of the different

37. Monteiro (1895).

38. Portugal. Ministério das Obras Públicas, Comércio e Indústria, Direcção-Geral do Comércio e Indústria (1905). 
MAP 2 - Southern Portugal, in grey, and the localities mentioned in this article

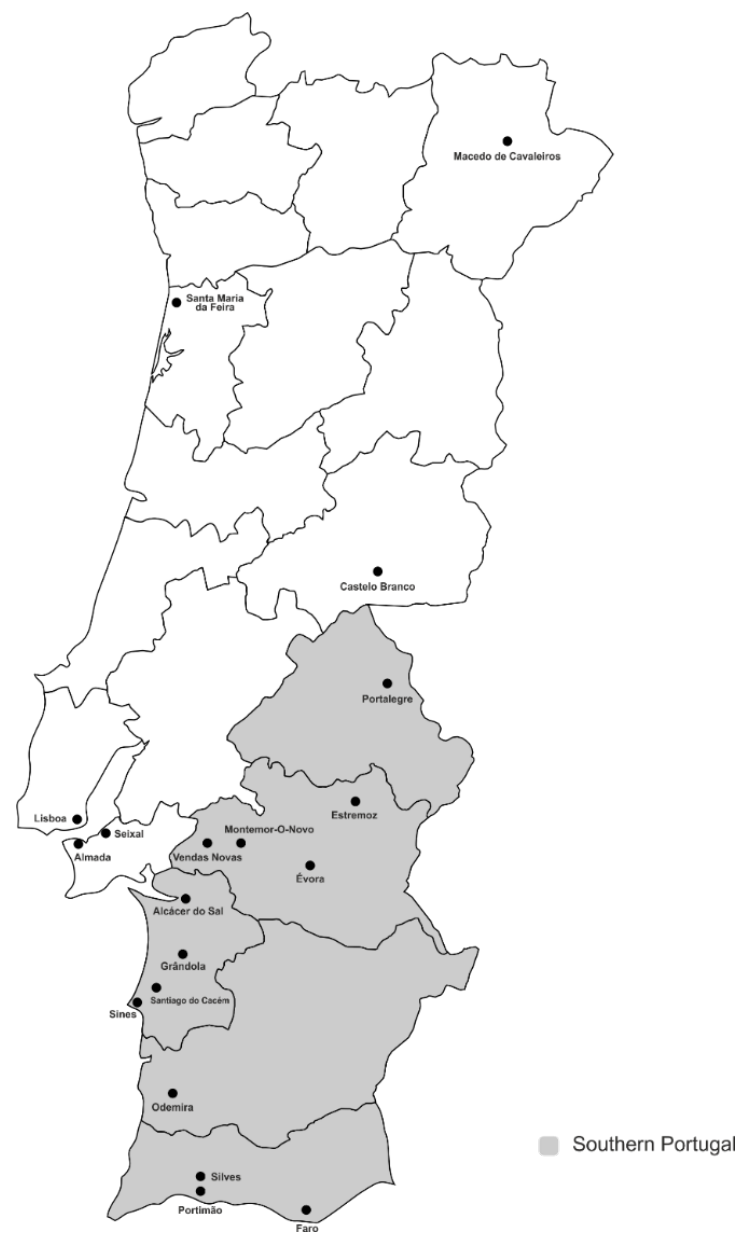

NUTS III that currently use the name Alentejo, i.e., Alto Alentejo, Alentejo Central and Alentejo Litoral, while the latter corresponds, as always, to NUT II and NUT III with the same name.

With about $32,250 \mathrm{~km}^{2}$, nearly $37 \%$ of Continental Portugal, this geographic area concentrated the majority of cork factories and employees by the late nineteenth century, as Graphic 1 demonstrates.

However, at the turn of the twentieth century, the core of the cork industry, especially the manufacturing industry, began to move towards the Lisbon Metropolitan Area, with an emphasis on the industrial belt of Lisbon and the municipalities of the South Bank of the Tagus River. ${ }^{39}$ Even so, by 1915, half

39. Fonseca (1996), p. 71. 
GRAPHIC 1 - Regional concentration of the cork industry in Portugal, 1890 (in \%)

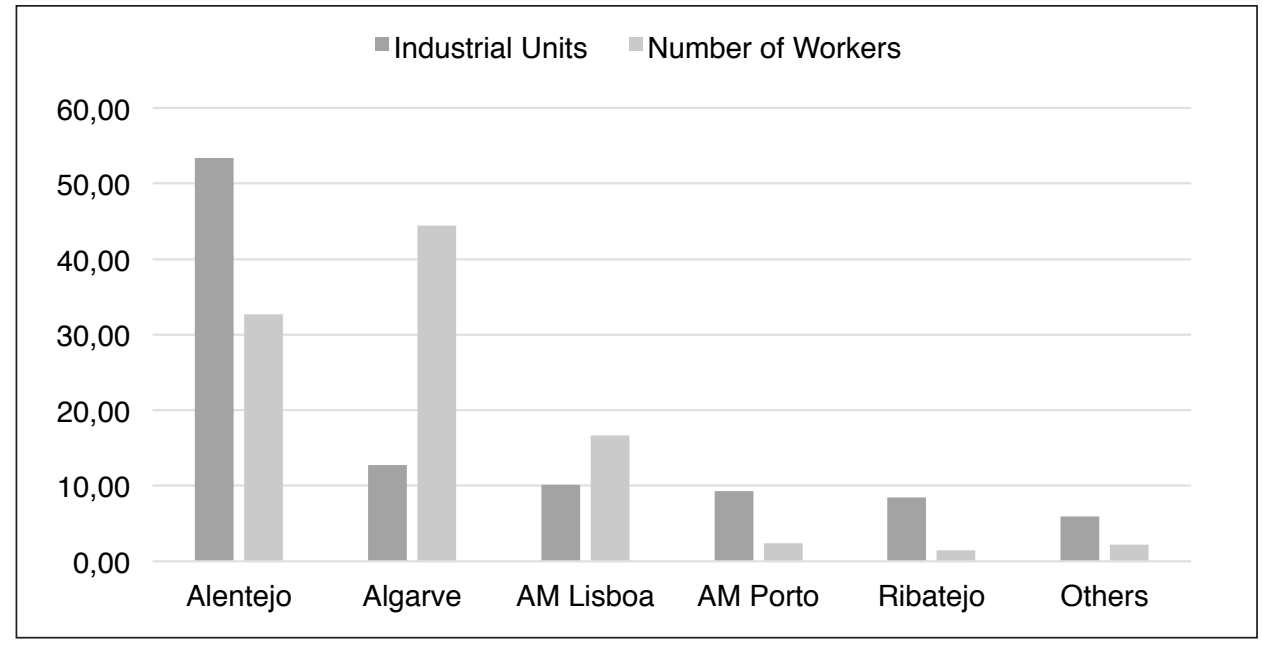

Source: Portugal. Ministério das Obras Públicas, Comércio e Indústria (1891).

of the cork industry and half of the employment were still concentrated in Alentejo and Algarve. ${ }^{40}$ Thus, it seems logical to affirm that the cork industry of the south of Portugal is quite representative of the generality of the Portuguese cork industry.

By analysing the cork industry of the south of Portugal, we try to understand the degree of mechanization of cork production and, within this, the application of machinery that used inanimate energy. This focus is due to the characteristics of the cork industry at the time, in which the production of cork stoppers was by far, and almost exclusively, the activity that generated the highest added value. We also explore local differences in this matter within the cork industry in southern Portugal.

\section{The Spanish cork industry and its "technological modernization"}

The cork industry was distributed very unequally in Spain, being located especially close to the main areas of cork oak tree implantation. Regardless of the existence of small cork industrial centres in the northwest of Spain, ${ }^{41}$ the industry was mainly concentrated in Catalonia, Extremadura and Andalusia. However, even within these regions, there were notable differences in their industrial areas, with the Catalan industry the core of manufacturing,

40. See the statistic available in Pereira (1915), p. 277.

41. Guerra Velasco (2015). 
since the majority of the industry installed in Extremadura and Andalusia was essentially "preparatory" ${ }^{42}$ However, as time went by, the manufacturing industry also developed in the south-west of Spain. ${ }^{43}$

Facing the already mentioned threat from the cork industries of more industrialized countries, Catalan entrepreneurs started a late but rapid process of modernization, which began in the mid-1880s with the arrival of the garlopa and continued with the introduction of machinery from the United States of America ${ }^{44}$ Thus, in 1886, the Josep Batet factory in Sant Feliu de Guíxols already had 33 garlopas in operation, while Martí Montaner, owner of a large factory in Palamós, equipped it, still in the nineteenth century, with modern emery machines. ${ }^{45}$ The rapid mechanization of the Catalan cork industry can be evaluated, for example, by the number of machines producing cork stoppers which in 1892, according to sources at the time, amounted to almost $600 .{ }^{46} \mathrm{At}$ the beginning of the twentieth century, the improvement of the mechanized production of cork stoppers and the implementation of new energetic possibilities, such as electric energy, led, progressively, to the moderate replacement of the garlopa with motorized machines of higher productivity. A good example is the town of Palafrugell where, in 1902, five motorized machines operated in the production of cork stoppers, a figure that rose in the following year to 18 and reached, in 1910, the number of $102 .{ }^{47}$ However, the generalization of the adoption of the American system would only occur after the end of the First World War. ${ }^{48}$

Consequently, the structure of the cork industry in Catalonia changed with the beginning of the replacement of human labour by capital, "proletarizing" the cork worker and reinforcing the creation of medium and large companies, due to the greater need of financial investment and of its optimization. On the other hand, motorized mechanization meant the feminization of cork stopper production, because from the moment that production stopped being artisanal work and became a mechanical process, the companies would choose to hire less expensive workers, i.e., women. Therefore, in 1919, in Llagostera, of the 254 workers in the local cork industry, 118 were women, and all 87 mechanical stopper makers were, in reality, female, a situation that was replicated in Palafrugell. ${ }^{49}$

Nevertheless, many of the manual producers were able to continue to exploit very specific niche markets, with several smaller and almost artisanal es-

42. Zapata Blanco (1996), p. 42.

43. Parejo Moruno, Faísca, Rangel Preciado (2013).

44. Parejo Moruno (2009), pp. 121-126.

45. Alvarado i Costa (2009), p. 34.

46. Vila Sagletti (1892), p. 68-69.

47. Alvarado i Costa (2009), p. 36.

48. Parejo Moruno (2009), pp. 124-125.

49. Alvarado i Costa (2009), p. 37. 
tablishments remaining in operation. This microenterprise system, with few personnel hired outside the family sphere, remained very common in Catalonia until the first decades of the twentieth century, when mechanization imposed the hegemony of the factories. ${ }^{50}$ In this sense, the ratio between the number of workers and machines, in 1892, in the province of Gerona, was 14.68 workers per machine, ranging from 11.70 in Figueres to 21.10 in Santa Coloma de Farners. ${ }^{51}$ On the other hand, some medium-sized companies only introduced the first garlopas in the early twentieth century ${ }^{52}$ while even in large companies manual production had a notable relevance until advanced dates, since some of the higher quality stoppers continued to depend on this type of work. ${ }^{53}$

In the Spanish regions of the southwest, the process of replacing labour with capital was slower and, in Extremadura, almost non-existent, causing it to lose importance in the Spanish context, both in terms of quantity and competitiveness. ${ }^{54}$

We can therefore conclude that, in Catalonia, the cork manufacturing industry started a late mechanization process, but did it in a rapid way. The choice was initially to follow the French method (use of the garlopa), however, gradually the American model, based on more productive machinery powered by inanimate energy, imposed. ${ }^{55}$ In the rest of Spain this process was much more restrained, not only in Extremadura and Andalusia, but also in

TABLE 1 - Regional mechanization of the Spanish cork industry in 1900

\begin{tabular}{lrrr}
\hline \multicolumn{1}{c}{ Region } & Type A & Type B $^{\mathbf{2}}$ & Type C $^{3}$ \\
\hline Catalonia & $57 \%$ & $45 \%$ & $71 \%$ \\
\hline Extremadura & $10 \%$ & $12 \%$ & $4 \%$ \\
\hline Andalusia & $30 \%$ & $43 \%$ & $25 \%$ \\
\hline Rest of Spain & $3 \%$ & $0,5 \%$ & $0 \%$ \\
\hline Total & $100 \%$ & $100 \%$ & $100 \%$ \\
\hline
\end{tabular}

Source: Zapata Blanco, 1996, 43.

1. Number of tables to make cork stoppers that have at least four seats for workers.

2. Number of machines for rounding corks stoppers.

3. Number of machines moved mechanically in the cork factories.

50. Sala, Nadal (2010), p. 76.

51. Espadalé (2002), p. 79.

52. Cases of the Bech de Careda, H.nos, see Alvarado i Costa (2002), pp. 118-120 or the Coris, see Alvarado i Costa (2004), p. 184.

53. Alvarado i Costa (2004), pp. 118-120.

54. Zapata Blanco (1996), p. 45.

55. On this subject see Parejo Moruno (2009), pp. 121-127. 
the cork industry in the northwest where mechanization was practically non-existent in the chronology of this article. ${ }^{56}$

\section{The mechanization of the Portuguese cork industry in the context of Portuguese industrialization}

It is common sense to consider that the use of new technologies played a significant role in the European industrialization, ${ }^{57}$ with the lack of capital for industrial purposes and the absence of appropriate "technological modernization" the classic factors appointed for the underdevelopment of the Portuguese industrial sector. ${ }^{58}$ The slow introduction of the steam engine, of the mechanical thresher, or the small number of spindles in the cotton textile industry are some of the examples of the late and slow mechanization of the Portuguese industry. ${ }^{59}$ However, several authors also recognize that from the end of the nineteenth century, the Portuguese industry experienced a considerable substitution of labour for capital, which helped to strengthen a sector that was constantly expanding, although slowly. As matter of fact, it is almost consensus in the Portuguese economic historiography that industrial development in Portugal in the nineteenth century was not deficient, with an average annual growth of $2.5 \% .^{60}$ This meant a higher rate of increase than that of Great Britain, France, and Spain, although still below many European countries, especially those that, like Portugal, had begun their process of industrialization later. ${ }^{61}$ From another perspective, despite the growth of the industrial sector, from $18.9 \%$ of the gross domestic product in 1880 to $27.1 \%$ in 1910 , agriculture remained the main sector of the Portuguese economy. ${ }^{62}$ However, the evolution of agriculture was rather timid at an average annual rate of $1 \%$ between 1850 and 1900, half of what was necessary for the Portuguese agricultural labour income to reach the European average at the beginning of the twentieth century. ${ }^{63}$ Therefore, this was a period of expansion for the Portuguese economy, but, in comparative terms, with poor results. Thus, the Portuguese gross national product per

56. Guerra Velasco (2015), p. 71. According to this author, the first garlopas were only introduced in these regions around 1914.

57. Lains (1995), p. 314.

58. Reis (1993), pp. 176-177; Lains (1995), p. 97.

59. Reis (1993), pp. 176-177; Mata (2005), pp. 172-173; Costa, Lains, Miranda (2014), pp. $310-311$

60. Lains (2003), p. 137; Lains (2005), pp. 259-283.

61. Reis (2007), p. 206.

62. Costa, Lains, Miranda (2014), pp. 315-317.

63. Costa, Lains, Miranda (2014), pp. 303-304. 
TABLE 2 - Development of the cork industry in Portugal

\begin{tabular}{ccccc}
\hline Year & $\begin{array}{c}\mathbf{N}^{\circ} \text { of preparatory } \\
\text { factories }\end{array}$ & $\begin{array}{c}\mathbf{N}^{\circ} \text { of manufacturing } \\
\text { factories }\end{array}$ & $\begin{array}{c}\text { Total number } \\
\text { of factories }\end{array}$ & $\begin{array}{c}\text { Total number } \\
\text { of workers }\end{array}$ \\
\hline 1880 & 16 & 29 & 45 & 1,612 \\
\hline 1894 & 37 & 61 & 98 & 3,616 \\
\hline 1900 & 36 & 79 & 115 & 5,000 \\
\hline
\end{tabular}

Source: Parejo Moruno, 2009, 88.

capita, which in 1860 corresponded to $86 \%$ of the average of the more developed countries, in 1913 had declined to $45 \% .{ }^{64}$

In this context of economic growth but which was somehow divergent regarding the more industrialized countries, the cork sector played an important role both in agroforestry and in industry. In fact, cork was the agroforestry product with the fastest growth, with an average annual growth rate close to $4 \%$ between 1850 and 1914 . In comparison, in the same period, wine had an average annual growth of $2.2 \%$; potatoes and rice of $0.78 \%$; olive oil of $0.68 \%$; and wheat, despite the various protectionist laws that were published in this period, did not exceed a modest $0.64 \% .^{65}$

In the industrial sector, throughout the second half of the nineteenth century, the cork industry was one of the fastest growing sectors in Portuguese industry. However, this "success" has to be put into perspective, since it was a very recent activity in Portuguese industrial history because the first factories only developed in a consolidated way from the $1830 \mathrm{~s} .{ }^{66}$ Nevertheless, if in 1850 the cork industry accounted for only $1.2 \%$ of all Portuguese industrial workers and $1.1 \%$ of the added value of the national industry, by 1910 these figures had risen to $8.9 \%$ and $6 \%$ respectively, making cork the fourth most relevant industry in the Portuguese secondary sector, after the textile, canning and metallurgical industries. ${ }^{67}$

However, perhaps even more important than the proportion of the cork industry in the Portuguese industrial sector, was its eminently exporting character. This aspect is especially relevant if we consider that several authors point out, as one of the main limitations of industrialization in Portugal, the smallness of the domestic market, which did not provide proper stimulation for the development of the Portuguese industry. Thus, exports would be the alternative route for the rapid and consistent industrialization of the national economy, as it was in the case of some Northern European countries. ${ }^{68} \mathrm{In}$ -

64. Reis (1993), p. 9.

65. Lains, Sousa (1998), p. 28.

66. Mendes (2002), p. 36.

67. Lains (2003), p. 138.

68. Reis (1993), pp. 20-22. 
deed, in the structure of Portuguese exports, the cork industry was, along with canning, the main contributor. In the 1880 s each represented about one third of all Portuguese industrial exports. ${ }^{69}$ This issue is so essential that, in one of his most known studies, Jaime Reis elaborated a counterfactual reality to understand if the internal transformation of all Portuguese raw cork production could have led the national economy to a significantly faster industrialization, putting the country on the path of convergence towards the more developed countries of the world. ${ }^{70}$ Although the author's conclusions have been negative, the entire context described in the preceding pages makes it interesting to understand the process of mechanization of the cork industry within the general mechanization of Portuguese industry, since it was one of the main Portuguese industrial sectors and with large export potential.

In 1903, Chief Engineer Adriano Monteiro, in what we would nowadays call the preface of the Estatística Industrial: Distritos de Évora, Beja e Faro, addressed the crisis that was raging in the Portuguese cork industry. In addition to the eternal "Questão corticeira", around the discussion of the government's customs policy of semi-processed or raw cork products, Adriano Monteiro points to the lack of mechanization as one of the main problems of the national cork industry. Thus, according to him,

[...] the foreign industry, which manufactures corks, is armed with the best material and personnel adapted for its mechanical use: it produces, therefore, much cheaper in order to beat our products in their markets, in spite of coming to buy us the raw material, in exchange for gold, and still burdened with the cost of transport $[\ldots] .^{71}$

However, he noted that on the part of the

[...] industry, sincere lovers of the cork cause [there is a strong will in] leaving the traditional manual work and using resolutely only the mechanic $\left[\ldots . . .^{72}\right.$

In fact, as we shall see, the mechanization of the cork industry in the south of Portugal was already a reality in expansion during these years and the process accelerated in the following decade.

Faced with the scarcity of sources, it is difficult to identify not only when the first cork production machine was introduced in Portugal, but also in what

69. Lains (1995), p. 64.

70. Reis (1993), pp. 9-33.

71. Portugal. Ministério das Obras Públicas, Comércio e Indústria, Direcção-Geral de Comércio e Indústria (1905), p. VIII. Translation by the author.

72. Portugal. Ministério das Obras Públicas, Comércio e Indústria, Direcção-Geral de Comércio e Indústria (1905), p. XXI. Translation by the author. 
industrial unit. In the Industrial Survey of 1881, only one machine for producing cork stoppers was registered on Portuguese soil, namely in the factory of Clemente Menéres in Macedo de Cavaleiros, in the northeast of Portugal. ${ }^{73}$ However, the shortcomings of the Industrial Inquiries, as explained in section 4 , make it only safe to assume what is actually declared, and omissions can't be interpreted as non-existent in reality. In this sense, we can mentione that Robinson's factory in Portalegre had already installed a steam engine in $1872^{74}$ not mentioned in this survey and, in 1881, had a 20 horsepower motor in order to move 12 lathes in the manufacture of lower quality cork stoppers. ${ }^{75}$

Nine years later, the Industrial Inquiry of 1890, despite maintaining many of the problems of its predecessor, presents a more complete scenario. Therefore, in this document, 71 cork stopper machines were identified in the Portuguese cork industry with some examples of a reasonable concentration of machinery. This is the case of Quintella \& Co., in Lisbon, which employed 120 workers together with 21 cork stopper machines and a horsepower engine, while at Avern, Sons \& Barris, in Silves (Algarve), 250 workers coexisted with 11 machines for the production of cork stoppers. ${ }^{76}$ In Alentejo, there were six factories where the manufacture of stoppers was, at least partially, mechanized, with the emphasis on Sande \& Co. in Santiago do Cacém, which, with only 16 workers, registered the use of five cork stopper machines; thus, the worker/machine ratio suggests that the production of corks in this factory would be almost entirely mechanized. ${ }^{77}$ The absence of the Robinson factory, as a result of George Robinson's resistance to complete the inquiry or to provide any information on the subject, prevents a more precise view of the degree of mechanization of the cork industry present in southern Portugal at the end of the nineteenth century. However, despite all its defects, it seems possible to say that in the 1880 s the process of mechanization of cork production was already underway in the south of Portugal, which is in line with the introduction of machinery in the cork industry of the Lisbon region where, for example, in 1896, William Rankin \& Sons already used 28 cork stopper machines. $^{78}$

By the same time, in the 1895 survey, 93 cork stopper machines were working in the cork industry present in the south of Portugal, not including Alto Alentejo, with some factories already showing relatively reasonable numbers. These are the cases, for example, of the ten machines belonging to Companhia de Cortiças de Portugal, in Estremoz; the 20 units working in Serrão, Strat

73. Portugal. Ministério das Obras Públicas, Comércio e Indústria (1881).

74. Guimarães (2005), p. 167.

75. Custódio (1999), p. 95.

76. Portugal. Ministério das Obras Públicas, Comércio e Indústria (1891).

77. Portugal. Ministério das Obras Públicas, Comércio e Indústria (1891).

78. Flores (2003), p. 89. 
TABLE 3 - Mechanization of the cork industry present in Baixo Alentejo, Alentejo Central and Algarve, in 1901-1903

\begin{tabular}{lcccc}
\hline Municipality & $\begin{array}{c}\text { Number of } \\
\text { boilers }\end{array}$ & $\begin{array}{c}\text { Number cork } \\
\text { machines }\end{array}$ & $\begin{array}{c}\text { Number } \\
\text { presses }\end{array}$ & $\begin{array}{c}\text { Number of } \\
\text { calibrators }\end{array}$ \\
\hline Montemor & 7 & 55 & 1 & 1 \\
\hline Estremoz & 3 & 23 & No data & No data \\
\hline Évora & 5 & 8 & 1 & 1 \\
\hline Odemira & 4 & 12 & 2 & 1 \\
\hline Silves/Portimão & 9 & 95 & 11 & 6 \\
\hline Faro & 9 & 18 & 8 & 1 \\
\hline Total & 37 & 211 & 23 & 10 \\
\hline
\end{tabular}

Source: Portugal. Ministério das Obras Públicas, Comércio e Indústria. Direção Geral do Comércio e Indústria, 1905.

\& Co., in Montemor-O-Novo; and the 12 cork stopper machines of the João Francisco de Sousa Prado factory in Odemira. There were also the use of engines, one of six horsepower and another of 14 horsepower, respectively, in Avern Sons \& Barris e G.N. Mascarenhas and Vilarinho \& Sobrinho, both from Silves. ${ }^{79}$ However, on the other hand, many factories maintained the manual process of cork stopper production without the use of any machinery, such as, for example, Baltazar Borba Vasques in Évora, and José dos Reis Outeiro in Silves.

Notwithstanding the number of small factories that continued to maintain manual production of cork stoppers, the process of the mechanization of the cork industry in the south of Portugal, not including Alto Alentejo, was well underway at the turn of the twentieth century. That can be seen since in a little more than a five years the number of cork stopper machines doubled and exceeded 200. This fact gains strength given the fact that the producer of the 1895 statistic was the supervisor of the 1901-1903 survey, making the comparison of the two sources a very safe exercise.

However, more revealing than counting the numbers of existing machinery is to relativize it by comparison with the manual producing of cork stoppers. Table 4 shows that at the turn of the century more than a quarter of the workers producing cork stoppers did it with the help of a machine, with municipalities, such as Montemor-O-Novo or Estremoz, where the manual workers were already in the minority. A decade later, another source, expressed in Table 5, confirms this scenario with the total workers using machines surpassing the manual workers. We can conclude that, although the three sources are not fully comparable, since the most recent one was produced in a context different from the first two and does not analyse exactly the same geo-

79. Monteiro (1895), p. 250-263. 
TABLE 4 - Mechanization in the production of cork stoppers in Alentejo Central, Baixo Alentejo and Algarve, 1901-1903

\begin{tabular}{lcc}
\hline Municipality & $\begin{array}{c}\text { Average number of cork } \\
\text { machines per factory }\end{array}$ & $\begin{array}{c}\text { \% of mechanical workers in } \\
\text { total cork stopper workers }\end{array}$ \\
\hline Montemor & 11.00 & 54.93 \\
\hline Estremoz & 7.67 & 52.63 \\
\hline Évora & 1.60 & 33.33 \\
\hline Odemira & 5.00 & 17.95 \\
\hline Silves/Portimão & 19.00 & 18.52 \\
\hline Faro & 2.25 & No data \\
\hline Total & 7.38 & 27.34
\end{tabular}

Source: Portugal. Ministério das Obras Públicas, Comércio e Indústria. Direcção Geral do Comércio e Indústria, 1905.

graphical area, it seems safe to say that the mechanization of cork stopper production in the southern Portuguese cork industry continued at a good pace.

A good example of a factory with a high degree of mechanized production is the José Lopes Burgos factory in Castelo Branco, a mere 35 kilometres from the northern border of the Alentejo. Founded in 1892, this factory produced cork stoppers, in 1911, either mechanically or manually. However, with a total of 251 workers, the machinery used was considerable, constituting, firstly, a 40 horsepower engine driven by two Babcock \& Wilcox boilers. In addition to this, it had 70 cork stopper machines, 14 cork board making machines, one machine to count cork stoppers, among many others. ${ }^{80}$ To the contrary, the factory of Leonardo José de Sousa, also in the same city and founded in 1889 but much smaller, employing only 24 workers, had three cork stopper machines but that weren't operational as all their cork stopper production was done manually. ${ }^{81}$

In addition to the investment in technological modernization, the reasonable rates of mechanization of the southern Portugal cork industry compared with that of Catalonia may also reflect a regional specialization. In such a scenario, the southern Portugal cork industry would essentially produce low and medium quality stoppers, thus explaining also the lesser preponderance of manual stopper production.

However, although the process of mechanization was already reasonably implemented in the decade of 1910, some sources suggest that this was mainly due to the use of machines moved by the force of the worker, probably garlopas

80. Portugal. Ministério das Obras blablá. Boletim do Trabalho Industrial (1911), p. 6-8.

81. Portugal. Ministério das Obras blablá. Boletim do Trabalho Industrial (1911), p. 10-12. 
TABLE 5 - Proportion of mechanical cork stopper workers in the total of cork stopper workers (1913-1917)

\begin{tabular}{lc}
\hline Industrial circumscription & \% of mechanical cork stoppers \\
\hline Castelo Branco & 56.49 \\
\hline Vendas Novas & 82.56 \\
\hline Évora & 23.92 \\
\hline Faro & 25.77 \\
\hline Total & 51.43
\end{tabular}

Source: Arquivo Nacional da Torre do Tombo, Ministério da Agricultura, Caixa 836, Maço 2.

or, at most, drilling machines with a pedal. This conclusion, though it has less solid bases than the previous one, can be drawn from both qualitative sources and from the quantitative analysis of the number of women in the production of cork stoppers by the relationship usually existing between the contracting of these and the use of machinery of inanimate energy. Thus, of a qualitative nature, Sales Gião states that the production of corks in Estremoz is carried out through "[...] machines, moved by the arms, or manually by the workers themselves [...]", 82 a description that he repeats for Évora, Odemira and Algarve, where "[...] stoppers are made with the machine moved by arms $[\ldots]$ ". ${ }^{83}$ On the other hand, and maintaining the idea of the recruitment of female workers linked to the automated mechanization of the cork industry, the number of women producing cork stoppers is significantly lower than that of men. Nevertheless, as we have seen, we have identified several examples of engines used in the production of cork stoppers such as: Robinson, in Portalegre; Avern Sons \& Barris e G.N. Mascarenhas, in Silves; Villarinho \& Sobrinho, in Silves; one unidentified factory, in Montemor-O-Novo, and José Lopes Burgos, in Castelo Branco.

In the Metropolitan Area of Lisbon, although the sources used in this article do not cover this region, the known cases already studied suggest that here mechanization also followed at a good pace. Thus, in 1896, William Rankin \& Sons, based in Almada, already used 28 garlopas in the manufacture of cork stoppers, ${ }^{84}$ while in 1905, in the towns on the south bank of the Tagus river, there were 36 engines in the cork industry with a total sum of 1,829 horsepower. ${ }^{85}$ Also when L. Mundet \& Son, Inc. settled in Seixal in 1905, the manage-

82. Portugal. Ministério das Obras Públicas, Comércio e Indústria, Direcção-Geral do Comércio e Indústria (1905), p. 15.

83. Portugal. Ministério das Obras Públicas, Comércio e Indústria, Direcção-Geral do Comércio e Indústria (1905), pp. 211-212.

84. Flores (2003), p. 89.

85. Flores (2003), p. 90. 
TABLE 6 - Discrimination by gender of mechanical cork stopper workers in Alentejo Central, Baixo Alentejo and Algarve, in 1901-1903

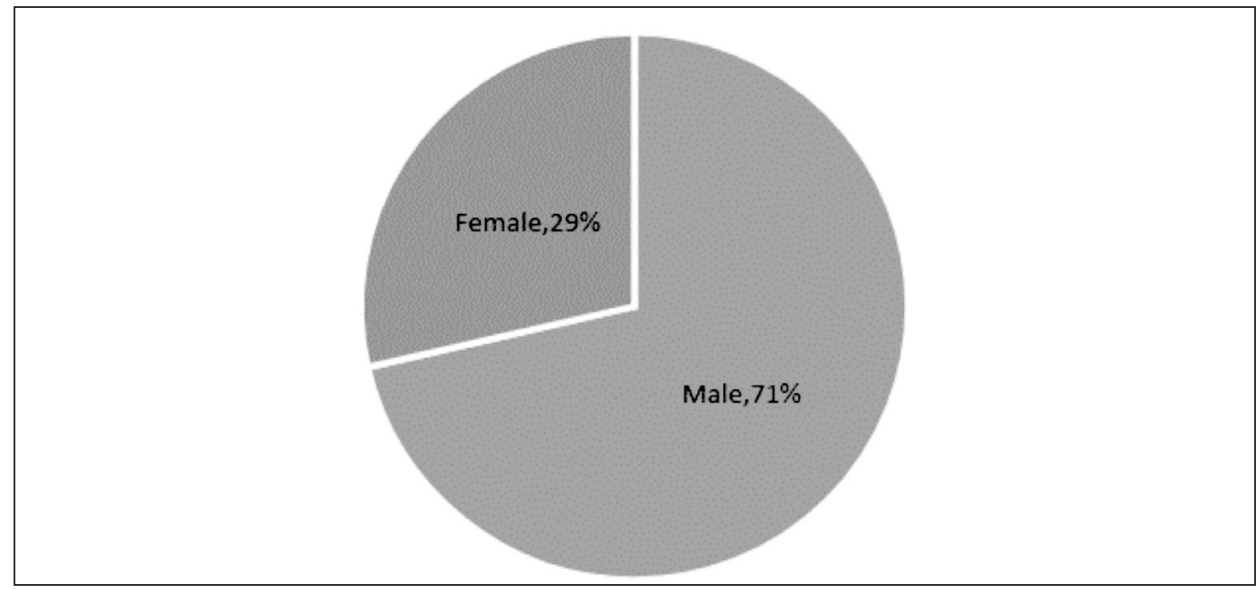

Source: Portugal. Ministério das Obras Públicas, Comércio e Indústria. Direcção Geral do Comércio e Indústria, 1905.

ment spent the first five years equipping the factory with machinery. These included emery machines, garlopas, and squaring machines. ${ }^{86}$

\section{Local characteristics of cork stopper production in southern Portugal}

Notwithstanding the previous conclusion, in reality the mechanization process of the cork industry in southern Portugal hid enormous local differences. For instance, in Évora the manual manufacture of cork stoppers predominated in a much more significant way than any other region of Alentejo, being only comparable to what was observed in Faro (Algarve). In fact, Ana Cardoso Matos had already pointed out this characteristic of the cork manufacturing industry of Évora ${ }^{87}$ very marked by the Catalan influence, especially around the village of Azaruja, something that Pere Sala and Jordi Nadal reinforce. ${ }^{88}$ Therefore, we confirm the low-tech approach that these authors identified in the region of Évora-Azaruja, which led to a business model very similar to that found in some parts of Catalonia until the first decades of the twentieth century. This business model was constituted by a large number of small family enterprises who managed to survive by supplying some

86. Filipe, Afonso (2010), p. 27.

87. Matos (1991)

88. Sala, Nadal (2010). 
specific products to medium and large industrial enterprises. Even if these small enterprises generated low incomes, many manual cork stopper producers preferred to keep their independence rather than submitting to the industrial wage of large factories. In times of crisis, they adapted their businesses by keeping only the most basic expenses, which was possible because this type of micro-industry requires only small investments and has a very small fixed cost structure. ${ }^{89}$ On the other hand, the strong Catalan influence in the local manufacturing industry, with its artisan knowhow, should have boosted this situation. In this sense, several applications sent to the Civil Government of Évora requesting licenses for the establishment of factories for cork stopper production, between 1913 and 1917, did not indicate the existence of any machinery for producing cork stoppers. This was the case of José Gomes Severino, João Valentim Teles and Rodrigues Fino \& Co., with the only machines being the ones related to the initial phase of preparing the cork, i.e., boilers and presses. ${ }^{90}$ Also in a scenario of low technological renewal was the cork industry of Odemira, as already noted by other authors, ${ }^{91}$ although the heterogeneity of the companies established here allowed for, alongside totally manual units, factories with some degree of mechanization, like the cases of João Francisco de Sousa Prado and Manuel Francisco dos Santos.

In a different scenario, the cork industry present around the Montemor-O-Novo/Vendas Novas axis, only about $60 \mathrm{~km}$ from Évora, was already deeply mechanized in the early twentieth century, with the mechanized production of cork stoppers being almost exclusive. In fact, it was precisely in one of the factories of Montemor-O-Novo that, in 1903, a machine with a six-horsepower engine was already in operation, and the number of female workers in cork stopper production, 25, was higher than that of men, 14, which was certainly not a mere coincidence. ${ }^{92}$ In Estremoz things seemed to be similar, where the mechanical workers constituted the majority of cork stopper producers.

Finally, in Algarve there were also two different realities. In Silves/Portimão, the low percentage of mechanical cork stopper producers in the total number of workers of this kind is not explained by the absence of mechanization. It was, in reality, the largest cork industry core in Portugal and there coexisted, with 95 cork stopper machines and the use of engines, more than 200 manual workers. However, in the municipality of Faro, which encompassed the cluster of the São Brás de Alportel cork industry, the situation

89. Matos (1991), p. 573; Sala, Nadal (2010), pp. 75-76.

90. Arquivo Distrital de Évora, Governo Civil, Licenciamento de Indústrias insalubres e tóxicas, 1913-1917.

91. Quaresma (2014), p. 114.

92. Portugal. Ministério das Obras Públicas Comércio e Indústria. Direcção-Geral do Comércio e Indústria (1905), p. 58-59. 
seemed to resemble that of Évora and Azaruja, with the presence of many small factories that produced stoppers essentially by manual work.

\section{Conclusion}

We conclude that the alleged "backwardness" of the cork manufacturing industry in the south of Portugal, in terms of its mechanization, related to the Spanish industry was, at most, not very significant from the chronological point of view, since a good part of the production was already done mechanically in the early twentieth century. That is to say, the beginning of this "modernization" must have taken place at the end of the nineteenth century, during the same period or shortly after it had taken place in Catalonia, the main and most advanced Spanish region in the cork industry. As a matter of fact, the general scenario of the cork industry present in southern Portugal seems similar to that described for Catalonia, i.e., a dual reality where mechanization was already widespread, but where the traditional cork industry remained active, possibly by exploring market niches with the production of high-quality cork stoppers. The relatively high mechanization rates in relation to the Catalan industrial arena may also reflect a greater Portuguese specialization in the production of low and medium quality cork stoppers, since those of high quality remained manually produced until later.

There were, however, strong regional differences in southern Portugal, which could be due to different stages of development and/or to the specialization of each area. Thus, in Evora, where the strong Catalan presence is well known, artisanal methods would be maintained and perhaps the production of high quality cork stoppers, while in Estremoz, and especially along the Vendas Novas/Montemor-O-Novo axis, the industry had already been reoriented to the mechanized production of corks. In the Algarve, it seems that mechanization and "craftsmanship" would coexist, since if the "[...] class [of manual cork stoppers] still has a large numerical representation $[\ldots],{ }^{93}$ the number of machines employed was not to be ignored, including engines, especially in some of the largest factories of Silves.

As for the type of machinery employed, it seems that there could be a slight difference in relation to the Catalan phenomenon. There is some evidence of the use of motorized machinery, but not a massive one, therefore it seems that the modernization of the cork industry present in the south of Portugal remained mostly, at least until the end of the Great War (1914-1918), by the use of the Garlopa. However, even in this aspect that seems to be generalized, there are regional differences, with the region of Silves in the use of

93. Soares, Neto, Mexia (1912), p. 37. 
engines, such as Vendas Novas / Montemor where there is also a large hiring of female workers, a situation associated with motorization of the production of cork stoppers. On the other hand, not only in Spain the use of machinery powered by inanimate energy will only be definitively imposed after the First World War, but also the existing data on the cork industry of the Lisbon region shows a mechanization technologically advanced.

Another important conclusion is the Portuguese cork manufacturing industry following the typical pattern of technological change in Portuguese industry. In other words, late modernization but then an accelerated phase, beginning in the late nineteenth century which, although not at the same level as that of the more developed countries, has to be considered.

In any case, and even taking into account all the nuances of a mixed and not yet fully defined scenario, as the Catalan cork manufacturing industry regained its role as the world's main production centre, the Portuguese cork manufacturing industry followed more or less the same path. Therefore, we can assume that, even in a position of relative subordination, the Portuguese cork manufacturing industry could provide some competition against the Spanish one. In fact, since the 1930s, all facets of the Portuguese cork business, including the manufacturing industry, began to lead world-wide. Therefore the Portuguese manufacturing industry couldn't have been, in the first two decades of the twentieth century, profoundly "delayed" in relation to the Spanish/Catalan cork manufacturing industry. Seen in the long run, the Portuguese cork business, which includes the industrial transformation, evolved naturally and positively since its beginnings in the first half of the nineteenth century. The delay in relation to Spain seems to have been due more to historical reasons than to any technological backwardness or less favourable institutional environment, since the "modern" exploitation of cork appeared in Portugal just under 100 years later than in Spain. Moreover, this is the conclusion of a recent study that, in addition to the industrial sector, analyses forest exploration and the economic policies of Spain and Portugal in the "long" nineteenth century. ${ }^{94}$

\section{Sources}

Arquivo Nacional da Torre do Tombo, Ministério da Agricultura, Caixa 836, Maço 2.

Arquivo Distrital de Évora, Governo Civil, Licenciamento de Indústrias insalubres e tóxicas, 1913-1917.

94. Faísca (2019). 


\section{References}

Alvarado i Costa, Joaquim (2002), El negoci del suro a l'Alt Empordà (segles XVIII-XIX), Museu del Suro, Palafrugell.

Alvarado i Costa, Joaquim (2004), Suro, carracs i taps. Llagostera, 1753-1934, Llagostera, Ajuntament de Llagostera.

Alvarado i Costa, Joaquim (2009), El negoci del suro a la comarca de la Selva: del segle XVIII a mitjan segle XX, Barcelona, Centre d'Estudis Selvatans.

Associação Portuguesa de Cortiça (2018), Anuário de cortiça 17/18, Santa Maria da Feira, Associação Portuguesa de Cortiça.

Branco, Amélia (2005), O Impacto das Florestas no Crescimento Económico Moderno durante o Estado Novo (1930-1974), Lisbon, Instituto Superior de Economia e Gestão.

Bombico, Sónia; CARneiro, André (2016), "Do Mar ao Montado: Evidências da utilização e exploração de cortiça na Lusitânia Romana”. In RANGEL PRECIADO, José; FAíscA, Carlos Manuel; Bombico, Sónia (eds.), El alcornocal y el negocio corchero: Una perspectiva histórica e interdisciplinar $=O$ montado de sobro e o setor corticeiro: uma perspetiva histórica e interdisciplinar, Badajoz, Diputación de Badajoz, pp. 19-45.

Branco, Amélia; Parejo Moruno, Francisco; Lopes, João Carlos; Rangel Preciado, Jose (2016), "Cambios en la localización de la industria corchera mundial. Una perspectiva histórica”, Revista de Estudios Regionales, no. 106, pp. 55-78.

Corticeira Amorim S.G.P.S., S.A. (2018), Relatório Anual Consolidado 2017, Santa Maria da Feira, Corticeira Amorim S.G.P.S., S.A.

Costa, Leonor Freire; Miranda, Susana Münch; LAINS, Pedro (2014), História Económica de Portugal, 3rd ed., Lisbon, A esfera dos livros.

Custódio, Jorge (1999), "Tecnologias e maquinismo na Avern, Sons \& Barris de Silves". In CustóDio, Jorge (coord.), Museu da Cortiça da Fábrica do Inglês: Exposição Permanente, Silves, Fábrica do Inglês, pp. 84-113.

ESPADALÉ, Josep (2002), "L'aplicació de màquines en la manufactura surotapera", Revista de Girona, no. 23, pp. 540-547.

FAíscA, Carlos Manuel (2019), El negocio corchero en Alentejo: explotación forestal, industria y política económica, 1848-1914, Badajoz: Universidad de Extremadura (PhD thesis awaiting defence).

FILIPE, Graça; AFONSO, Fátima (coord.) (2010), Quem diz cortiça, diz Mundet. Seixal, Município de Seixal.

Flores, Alexandre M. (2003), Almada na História da indústria corticeira e do movimento operário: da Regeneração ao Estado Novo (1860-1930), Almada, Câmara Municipal de Almada.

FonseCA, Helder (1996), O Alentejo no século XIX: Economia e atitudes económicas, Lisbon, Imprensa Nacional - Casa da Moeda.

García Pereda, Ignacio (2008), Joaquim Vieira Natividade: 1899-1968, ciência e política do sobreiro e da cortiça, Lisboa, Euronatura. 
García Pereda, Ignacio (2009), Junta Nacional da Cortiça (1936-1972), Lisboa, Euronatura.

Grupo de Estudios de Historia Rural (1999), "Armstrong Cork Company, Pittsburgh-Sevilla, 1878-1915”. In GUTIÉRREZ, Miquel (coord.), Doctor Jordi Nadal: La Industrialización y el desarrollo económico de España. Vol. II, Barcelona, Universitat de Barcelona, pp. 1308-1330.

Guerra Velasco, Juan Carlos (2015), "La industria corcho-taponera en el noroeste de España: origen y evolución de una actividad de perfil artesanal (1827-1977)", Revista de Historia Industrial, no. 57, year XXIV, pp. 55-86.

Guimarães, Paulo (2005), Elites e Indústria no Alentejo (1890-1960): Um estudo sobre o comportamento económico de grupos de elite em contexto regional no Portugal contemporâneo, Évora, Colibri.

JúnIOR, João Augusto Ferreira da Costa (1923), "Indústria Corticeira”, Revista do Instituto Superior de Contabilidade de Lisboa, no. 6, pp. 321-337.

LAIns, Pedro (1995), A economia portuguesa no século XIX: Crescimento económico e comércio externo, Lisbon, Imprensa Nacional-Casa da Moeda.

Lains, Pedro (2003), Os progressos do atraso: uma nova História Económica de Portugal, Lisbon, Imprensa de Ciências Sociais.

LAIns, Pedro; Sousa, Paulo Silveira e (1998), "Estatística e produção agrícola em Portugal”, Análise Social, vol. XXXIII, no. 149, pp. 935-968.

MATA, Eugénia Maria (2005), "O capital”. In LAINS, Pedro; Silva, Álvaro Ferreira da, História Económica de Portugal. Vol. II: O século XIX, Lisboa, Imprensa de Ciências Sociais, pp. 153-189.

Matos, Ana Cardoso de (1991), "A indústria no distrito de Évora, 1836-90”, Análise Social, vol. XXVI, no. 112-113, pp. 561-581.

Mendes, Américo (2002), A economia do sector da cortiça em Portugal: evolução das actividades de produção e de transformação ao longo dos séculos XIX e XX, Porto, Universidade Católica Portuguesa.

Monteiro, Adriano (1895), "A industria da cortiça no districto de Evora", Boletim da Propriedade Industrial, 2nd series, 12 th year, nos. 3-8 and nos. 69-80, the last numbers were published in 1905.

Oliveira, Manuel Alves; Oliveira, Leonel Moreira (1991), A cortiça, Lisbon, Grupo Amorim.

Parejo Moruno, Francisco (2009), El negocio de exportación corchera en España y Portugal durante el siglo XX: câmbios e intervención pública, Badajoz, Universidad Extremadura, 2009.

Parejo Moruno, Francisco; Faísca, Carlos Manuel; Rangel Preciado, Jose (2013), "Los orígenes de las actividades corcheras en Extremadura: El corcho extremeño entre catalanes e ingleses", Revista de Estudios Extremenhos, vol. LXIX, no. I, pp. 461490 .

Pereira, José Campos (1915), A propriedade rústica em Portugal: superfícies, produções, rendimentos, valores, Lisbon, Imprensa Nacional. 
Portugal. Ministério das Obras Públicas, Comércio e Indústria. Direcção-Geral do Comércio e Indústria (1911), Boletim do Trabalho Industrial, Lisbon, Imprensa Nacional, no. 63 , pp. 6-20.

Portugal. Ministério das Obras Públicas, Comércio e Indústria. Direcção-Geral do Comércio e Indústria (1881-1883), Inquérito Industrial de 1881, Lisbon, Imprensa Nacional.

Portugal. Ministério das Obras Públicas, Comércio e Indústria. Direcção-Geral do Comércio e Indústria (1891), Inquérito Industrial de 1890, Lisbon, Imprensa Nacional.

Portugal. Ministério das Obras Públicas, Comércio e Indústria. Direcção-Geral do Comércio e Indústria (1905), Estatística industrial: Districtos de Évora, Beja e Faro, Lisbon, Imprensa Nacional.

Quaresma, António Martins (2014), O Rio Mira: no sistema portuário do litoral alentejano (1851-1918), Lisbon, Âncora.

REIS, Jaime (1993), O atraso económico português (1850-1930), Lisbon, Imprensa Nacional-Casa da Moeda.

REIS, Jaime (2007), "A industrialização num país de desenvolvimento lento e tardio: Portugal, 1870-1913”. In Lains, Pedro; Ferreira, Nuno Estêvão, Portugal em Análise, Lisbon, Imprensa de Ciências Sociais, pp. 199-223.

SAlA, Pere (2000), "Tecnologia, empresa i mercat en les industries del suro". In AAVV (coords.), Tècnics i tecnologia en el desenvolupament de la Catalunya Contemporània, Barcelona, Enciclopèdia Catalana, 2000, pp. 280-287.

SAla, Pere; NADAl, Jordi (2010), La contribució catalana al desenvolupament de la indústria surera portuguesa, Barcelona, Generalitat de Barcelona.

SAla, Pere; NADAL, Jaume (2013), Francisco Oller: calidad de líder, s.1., Nexe Impressiones.

Santos, Carlos Oliveira (2009), "Dom Pérignon, ilusiones y realidades", Floresta Mediterránea, Revista del Monte, la Dehesa y el Vino, year 6, no. 2, pp. 29-33.

SiLva, Luísa Viera da; GARCIA, João Carlos (1981), "O Inquérito Industrial de 1881, nota sobre um centenário", Finisterra, no. 32, pp. 318-329.

Simpson, James (2011), Creating wine: The emergence of a world industry, 1840-1914, Princeton, Princeton University Press.

SoAres, José António d'Oliveira; Netto, Carlos Amaral; MexiA, Joaquim Nunes (1912), Produção e industria corticeira, Lisbon, Typ. A editora.

Soldevila i Temporal, Xavier (2009), "Suredes i suro al Baix Empordà medieval". In Zapata Blanco, Santiago (coord.), Suredes $i$ indústria surera: avui, ahir $i$ demà $=\mathrm{Al}$ cornocales e industria corchera: hoy, ayer y mañana $=$ Cork oak woodlands and cork industry: present, past and future, Palafrugell, Museu del Suro, 2009, pp. 594-602.

Vila Saglietti, Hermenegildo (1892), O Sobreiro (el alcornoque) y su explotación comercial ante las relaciones internacionales hispano-portuguesas, Gerona, Imp. Paciano Torres.

Voth, Andrëas (2009), "Cambios en la geografia del corcho en Europa". In ZAPATA BLANCO, Santiago, Suredes i indústria surera: avui, ahir i demà = Alcornocales e indus- 
tria corchera: hoy, ayer y mañana = Cork oak woodlands and cork industry: present, past and future, Barcelona, Museu del Suro de Palafrugell, pp. 568-594.

ZaPATA Blanco, Santiago (1996), "Corcho extremeño y andaluz, tapones gerundenses”. Revista de Historia Industrial, no. 10, pp. 37-68.

Zapata Blanco, Santiago (2002), "Del suro a la cortiça: el ascenso de Portugal a primera potencia corchera del mundo". Revista de Historia Industrial, no. 22, pp. 109-137. 


\title{
Lagging behind or catching up? The mechanization of the Portuguese cork industry (1880-1914)
}

\begin{abstract}
In the second half of the nineteenth century the cork industry mechanized the production of cork stoppers, the main and, almost, the only cork product of that time. This movement began in the mid-nineteenth century in the most industrialized and non-cork forest countries, threatening the dominant position of the Spanish cork industry, located mainly in Catalonia. Subsequently, from the 1880 s, the Catalan industry began a rapid process of mechanization, regaining part of its global prominence in the transformation of cork. This article explores the mechanization of the Portuguese cork industry with the objective, on the one hand, of understanding if there was a delay in relation to the Catalan process and, on the other hand, of tracing the technological modernization of the Portuguese cork industry within the general picture of Portuguese industry.
\end{abstract}

KEYWORDS: Portuguese cork industry, cork stopper, nineteenth century, technological innovation

JEL CODES: N53, L73, O31, O33

\section{¿Retraso o modernización? La mecanización de la industria portuguesa del corcho (1880-1914)}

\section{RESUMEN}

En la segunda mitad del siglo XIX la industria corchera mecanizó la producción de tapones, el principal y casi el único producto corchero de la época. Este movimiento se inició, a mediados del siglo XIX, en los países más industrializados y sin producción forestal de corcho, amenazando la posición dominante de la industria corchera española, ubicada esencialmente en Cataluña. Posteriormente, a partir de la década de 1880, la industria catalana inició un rápido proceso de mecanización, retomando parte de su prominencia global en la transformación de corcho. En este artículo se analiza la mecanización de la industria del corcho portugués con el fin, por una parte, de entender si hubo un retraso en relación con el proceso catalán y, en segundo lugar, para colocar la modernización tecnológica de la industria del corcho portugués en el cuadro general de la industria portuguesa.

PALABRAS ClAVE: industria corchera portuguesa, tapón de corcho, siglo diecinueve, innovación tecnológica

Códigos JEL: N53, L73, O31, O33 